\title{
Non-conventional textile structures with technical destination, designed and developed at S.C. Cora Trading \& Service S.R.L.
}

\section{Structuri textile neconvenționale cu destinație tehnică, proiectate și dezvoltate}

la S.C. Cora Trading \& Service S.R.L.

Fibrele de lână sunt o resursă naturală, regenerabilă, durabilă, cu un impact redus asupra mediului și un potențial enorm pentru omenire. În conditiile în care populația Terrei se înmulțește exponențial, materiile prime sunt din ce în ce mai puține, o afacere bazată pe prelucrarea materiilor prime regenerabile, în special a fibrelor de lână, are mari șanse de supraviețuire și dezvoltare.

România, cu o economie agrară foarte dezvoltată, are o populație de aproape 10 milioane de ovine și o producție de peste 16.000 tone de lână medie și grosieră. Având în vedere necesitatea de a stabili cerințe minime de performanță energetică pentru clădirile noi și pentru renovarea majoră a celor existente la nivelul Uniunii Europene, este necesară dezvoltarea de noi materiale și tehnologii, astfel încât posibilitatea de a valorifica lâna pentru domeniul construcților să poată fi un element functional pe termen lung.

Această lucrare prezintă rezultatele experimentale ale caracteristicilor a 4 structuri textile neconvenționale (STN) realizate din fibre de lână 100\%, proiectate și dezvoltate la S.C. Cora Trading \& Service SRL, pe tehnologia proprie, existentă și adaptată. Amestecul fibros utilizat, care constă atât din lână de tăbăcărie, cât și din lână de tunsoare, permite dezvoltarea unor structuri inovatoare, cu potențial de utilizare pentru capacitatea lor de izolare termică și cu un mare potențial de dezvoltare durabilă pentru producător.

Cuvinte-cheie: lână grosieră de tunsoare, lână de tăbăcărie, structuri textile neconvenționale, conductivitate termică

\section{Non-conventional textile structures with technical destination, designed and developed at S.C. Cora Trading \& Service S.R.L.}

Wool fibers are a natural, renewable, sustainable, low impact on the environment, with huge potential for humanity. Given the exponential growth of the Earth's population, raw materials are getting less and less, a business based on the processing of renewable raw materials, especially wool fibers, has a high chance of survival and development.

Romania, with an overwhelming agrarian economy, has a population of nearly 10 million sheep and a production of over 16,000 tons of medium and coarse wool. Given the need to set minimum energy performance requirements for new buildings and for the major renovation of existing ones at European Union level, the development of new materials and technologies is necessary, so that the opportunity to capitalize on wool for buildings be a workable item on long term.

This paper presents the experimental results of the characteristics of 4 non-conventional textile structures (UTS) made of $100 \%$ wool fibers, designed and developed at S.C. Cora Trading \& Service SRL, on their existing adapted technology. The fibrous blend used, consisting of both tanning wool and coarse shared wool allow development of innovative structures, with potential of use for their thermal insulation capacity and great potential of sustainable development of the manufacturer.

Keywords: coarse wool fibers, tanned wool fibers, non-conventional textile structures, thermal conductivity

\section{INTRODUCTION}

European Union targets by 2030 include creating a cleaner and healthier climate. Investments for improving energy efficiency in buildings, related to ensuring a clean, non-polluting environment in a sustainable way are a priority of the governments of the European Union countries, in the context of the reduction of greenhouse gases [1, 2, 3].

Under the Energy Performance of Buildings Directive, EU countries have to set minimum energy performance requirements for new buildings and major renovation of existing ones [3]. In this directive, the action „Accelerating the European Energy System Transformation" refers to "Developing new materials and technologies, energy efficiency solutions for buildings". It is estimated that Romania will become one of the largest European sheep breeders, sheep reared for meat, so the opportunity to exploit wool in construction can be a long-term exploitable item.

Wool has a huge potential for the use of technical textiles [5, 6], thanks to its essential and unique characteristics such as: thermal resistance of high values, even in humidity conditions; capacity to minimize thermal and heat variation in humidity conditions; moisture management capacity; capacity to minimize condensation (does not favor mold growth), absorption capacity of volatile organic compounds, formaldehyde, sulfur dioxides, nitrogen oxides and carbon dioxide in the atmosphere; hypoallergenic and nontoxic character [7]; airborne and surface noise reduction capacity (reduction factor $\geq 90 \%$ ), heat transfer capacity, self-extinguishing capacity in contact with 
fire sources, biodegradable and compostable character $[8,9,10]$.

The paper proposes the presentation of experimental results of non-conventional textile structures (NTS) from $100 \%$ wool fibers, designed and developed at S.C. Cora Trading \& Service SRL, on their existing adapted technology, with potential for use in the field of construction, thanks to the thermal insulation properties $[11,12,13,14]$. The particularity of these structures is the presence in the fibrous blend of both tanned wool fibers and sheared thick wool fibers, with a low degree of valorization, currently, in Romania.

\section{EUROPEAN CONSTRUCTION MATERIAL MARKET}

Thermal insulation materials in buildings, which amounted to $\sim 7.4$ million tons in 2014 , corresponding to a volume of $\sim 234$ million $\mathrm{m}^{3}$, are essential for increasing energy efficiency in buildings, as construction consumes more than $40 \%$ of the amount of energy of the European Union and account for about $35 \%$ of all greenhouse gases [3]. Old buildings have the greatest potential for increasing energy efficiency ( 36\% by 2030). The annual compound growth rate of the production and consumption of thermal insulation materials is projected to be $4.5 \%$ by 2027 [3]. The market of thermal insulation materials in buildings is vast, with several identified classes, which are presented in the table 1.

The competitiveness of the thermal insulating material market is affected by the increasing demand, the improvement of the standards in the field, the requirements for improving the quality of insulating materials and the reconfiguration of the European construction industry $[3,4,15]$. The distribution chain of thermal insulation materials is shown in figure 1.

The essential parameters that are taken into account both by manufacturers and by the end users of thermal insulation are: the thermal insulation potential,

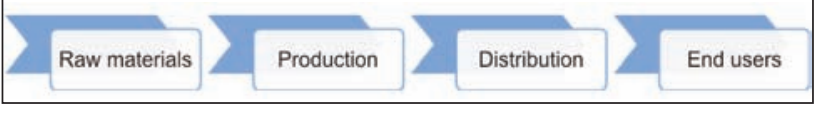

Fig. 1. Distribution chain of insulation materials [3]

the environmental relation, the protection factors (fire resistance) and the price.

An element that plays a significant role in calculating the cost of an insulation material is the provided safety and the quality of the insulated interior air [1, 16]. In this context, fire behavior is carefully studied, both in terms of damage in the event of a fire, but especially because of the toxic gases that it discharges during combustion. These gases can cause serious illness or even death [2].

Although the structures derived from organic, vegetal and animal materials occupy a secondary place in the thermal insulation market in the European Union (thermal insulation of wool occupying 1\%), their development potential is very developed in the conditions of sustainable development [4]. Thermal wool insulation does not support burning. Due to the nitrogen $(16 \%)$ and sulfur $(3-4 \%)$ content, in the chemical structure, wool fibers show the highest fire resistance of natural fibers (flame resistant fibers) (table 2). The assessment of the degree of flammability (the ability to ignite and burn) in textile materials is done by determining the limiting oxygen index (LOI - \%) [16]. Wool textiles protect (temporarily) the propagation of outside fire inside a home or vice versa, and when exposed to the flame they do not release toxic substances $[1,16]$.

\section{MATERIALS AND METHODS}

In order to obtain an experimental model (EM) of non-conventional textile structures (NTS) [18], a fibrous blend was designed, as shown in table $3[17$, 20, 21].

\begin{tabular}{|c|c|c|}
\hline \multicolumn{3}{|r|}{ INSULATION MATERIAL AT EU LEVEL [3] } \\
\hline No. & Class & Type \\
\hline 1 & Inorganic mineral fibrous & Stone wool; glass wool; slag wool \\
\hline 2 & Organic fossil fuel derived & $\begin{array}{c}\text { Polyurethane (PU); Expanded polystyrene (EPS); Extruded polystyrene (XPS); } \\
\text { Polyisocyanurate (PIR); Phenolic foam }\end{array}$ \\
\hline 3 & Organic plant/animal derived & $\begin{array}{l}\text { Cellulose; Woodfibre; Cork; Sheep's wool; Cotton; Hemp; Flax; } \\
\text { Compressed straw }\end{array}$ \\
\hline 4 & Innovative & $\begin{array}{l}\text { Biopolymers; Nano-coatings; Aerogel; Vacuum insulation panels; Nano-cellular } \\
\text { foam; Phase change materials (PCM); Advanced insulation foams }\end{array}$ \\
\hline 5 & Other & Cellular Glass; Aerated glass; Vermiculite; Expanded clay pellets; Foil products \\
\hline
\end{tabular}

\section{LIMITING OXYGEN INDEX OF SHEEP'S WOOL [16]}

LOI limiting oxygen index (\%) - minimum oxygen quantity to burn Sheep wool \begin{tabular}{|c|c|} 
Materials with LOI>25\% burn quickly & $\begin{array}{c}\text { Materials with LOI<25\% do not support } \\
\text { burning }\end{array}$
\end{tabular} 25.2 


\begin{tabular}{|c|c|c|}
\hline \multicolumn{3}{|c|}{$\begin{array}{l}\text { BLEND RECIPE (BR) - SHARES OF THE } \\
\text { COMPONENTS }\end{array}$} \\
\hline Components, P1 & \begin{tabular}{|c|} 
Fibre \\
fineness \\
\end{tabular} & $\begin{array}{c}\text { Weight } \\
\text { percentage wt. } \% \\
\end{array}$ \\
\hline 1. Sheared/virgin wool & \multirow{2}{*}{$\begin{array}{l}\text { Medium, } \\
\text { coarse wool }\end{array}$} & 50 \\
\hline 2. Tanned wool & & 50 \\
\hline
\end{tabular}

The main characteristics of blend recipe are presented in table 4.

The designed fiber blend was processed on two adapted technological flows, available at SC Cora Trading \& Service (figure 2), which includes 5 preliminary processing operations, web and batt forming operations, mechanical bonding operations (to obtain NTs) and

Table 4

\begin{tabular}{|c|c|c|}
\hline \multicolumn{3}{|c|}{ TECHNICAL SPECIFICATION ON THE VARIATION } \\
LIMITS OF THE FIBER BLEND CHARACTERISTICS \\
\hline \multirow{2}{*}{ Fiber characteristics } & \multicolumn{2}{|c|}{ Value } \\
\cline { 2 - 3 } & Average & CV, $\%$ \\
\hline Diameter, $\mu \mathrm{m}$ & 32,986 & 36,855 \\
\hline Length, mm & 64,33 & 74,97 \\
\hline Elongation to break, \% & 29,675 & 0,460 \\
\hline Breaking force, cN & 30,825 & 0,637 \\
\hline $\begin{array}{c}\text { Content of impurities, \% } \\
\text { (vegetable + mineral) }\end{array}$ & 0,8 & - \\
\hline $\begin{array}{c}\text { Soluble substances in organic } \\
\text { solvents, \% }\end{array}$ & 4,06 & - \\
\hline Index of solubility in alkali, \% & 12,69 & - \\
\hline
\end{tabular}

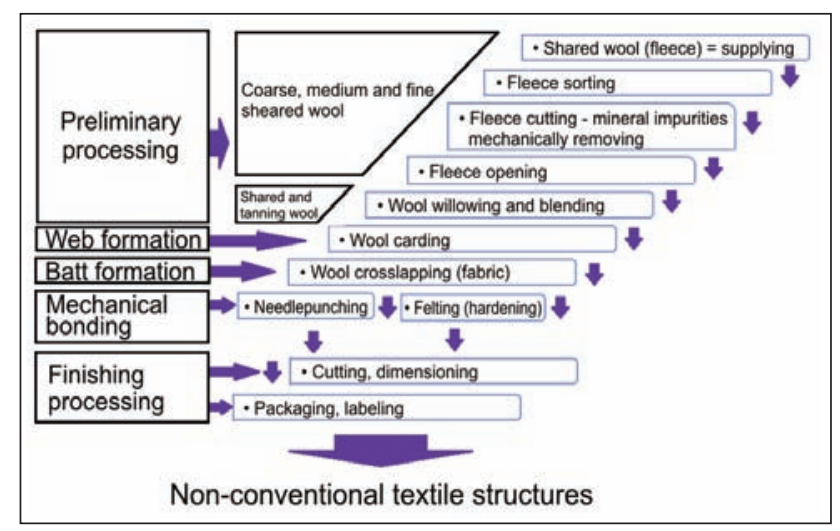

Fig. 2. Technological flow of non-conventional textile structures for thermal insulation [22]

final finishing operations $[10,19,20]$ (table 5). The high degree of impurities imposed the use of 5 primary processing operations, which can eliminate about $50-60 \%$ of these matters (vegetable matter and dirt) [21].

\section{EXPERIMENTAL}

Using the technologies presented in figure 2, four experimental models (EM) of NTS, encoded S1 (figure $3, a$ ), S2 (figure $3, b$ ), S3 (figure $3, c$ ) and S4 (figure $3, d$ ) were made. The four NTS vary function of thickness, specific mass (density) and bonding/felting technology.

The NTS experiment matrix (identified in figure $3, a-$ $\mathrm{S} 1$, figure $3, b-\mathrm{S} 2$, figure $3, c-\mathrm{S} 3$ and figure $3, d-$ S4) is shown in table 6.

\begin{tabular}{|c|c|c|c|}
\hline \multicolumn{2}{|c|}{ TECHNOLOGICAL PARAMETERS FOR NON-CONVENTIONAL TEXTILE STRUCTURES PRODUCTION, } \\
AVAILABLE TO SC CORA TRADING \& SERVICE SRL [22]
\end{tabular}




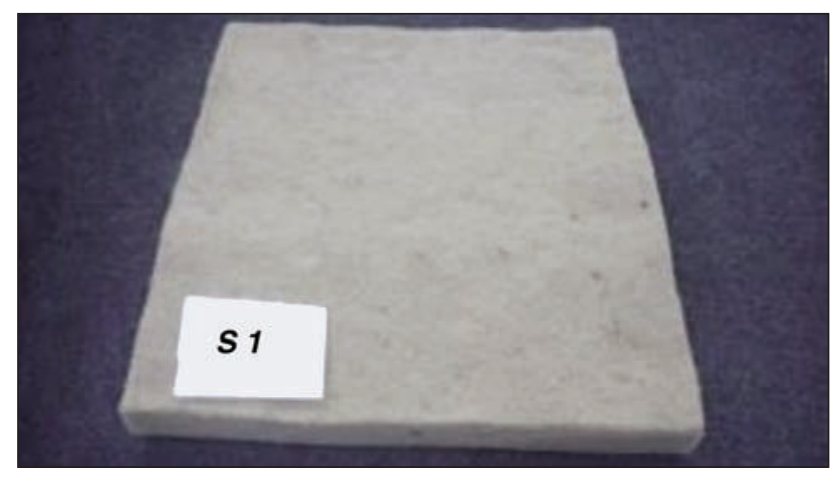

a

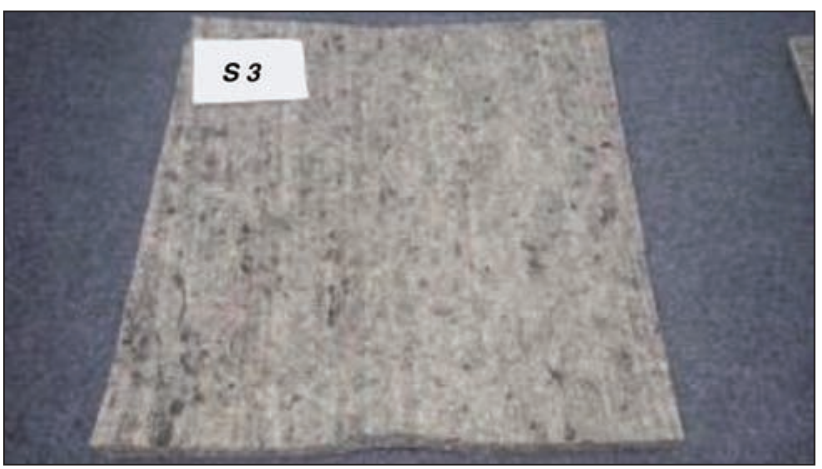

Fig. 3. STN a) $S 1$, b) $S 2$, c) $S 3$, d) $S 4$

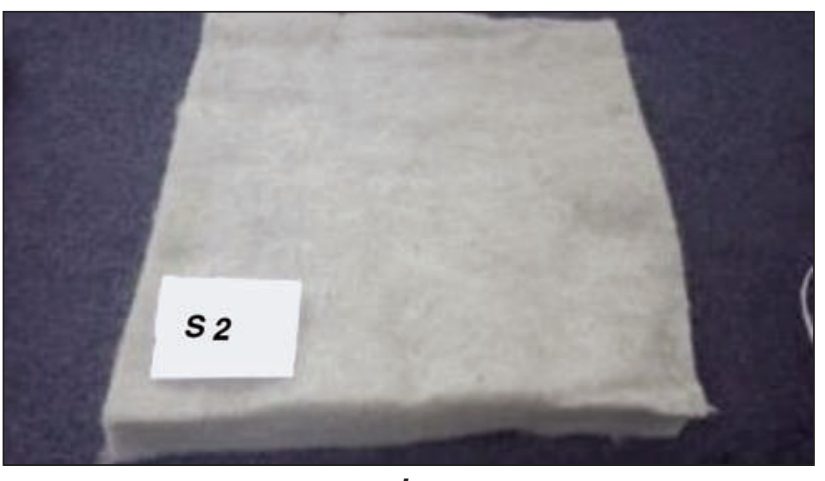

$\boldsymbol{b}$

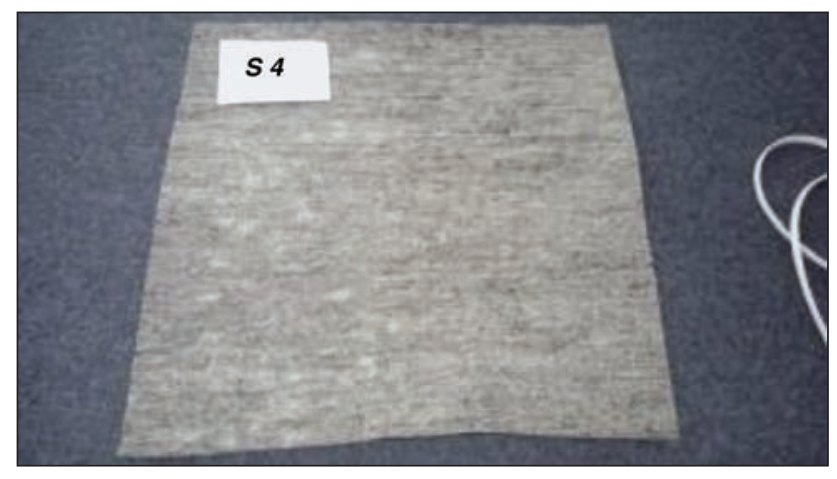

d
Table 6

\begin{tabular}{|l|c|c|c|}
\hline \multicolumn{4}{|c|}{ EXPERIMENTAL MATRIX } \\
\hline \multicolumn{3}{|c|}{ Experimental matrix } & Obtaining technology \\
\cline { 2 - 4 } & S1 & $\mathrm{x}$ & $\mathrm{T}$ \\
\hline \multirow{3}{*}{$\begin{array}{l}\text { Obtained } \\
\text { structure }\end{array}$} & $\mathrm{S} 2$ & $\mathrm{x}$ & \\
\cline { 2 - 4 } & $\mathrm{S} 3$ & & $\mathrm{x}$ \\
\cline { 2 - 4 } & $\mathrm{S} 4$ & & $\mathrm{x}$ \\
\hline
\end{tabular}

Legend:

T1 - technology to obtain voluminous STNs, bonded by hardening; T2 - technology for obtaining STN with low degree of volume, bonded by needle punching; S1 - STN with specific mass imposed in the range $2100 \mathrm{~g} / \mathrm{m}^{2} \pm 5 \%$, made by $T 1$ technology; S2 - STN with specific mass imposed in the range of $1700 \mathrm{~g} / \mathrm{m}^{2} \pm 5 \%$, made by T1 technology; S3 - STN with specific mass imposed in the range of $2700 \mathrm{~g} / \mathrm{m}^{2} \pm 5 \%$, made by T2 technology; S4 - STN with specific mass imposed in the $900 \mathrm{~g} / \mathrm{m}^{2} \pm 5 \%$ range, made by $T 2$ technology.

The technological variants of EM: S1, S2, S3 and S4, in the form of fibrous panels, have been analysed in terms of field of use specific functionalities: physical analysis (mass/unit area, thickness) and functional (thermal conductivity, fire behaviour, electrical resistivity).

\section{RESULTS}

\section{Mass per unit area}

The mass/unit area of the structures was obtained by overlapping the fibrous batts obtained from cross-laping, weighed in advance.

A number of batts have been folded successively until aim posed specific mass and weight, possible to consolidate, is reached. The values obtained are shown in table 7.

Regarding the specific mass of S1, S2 S3 and S4 NTS, for the obtained values it can be mentioned that $\mathrm{S} 2$ has a specific mass by $17,29 \%$ lower than $\mathrm{S} 1$, this being the minimum specific mass, possibly obtained by this bonding technology. Below this value, keeping the consolidation conditions constant (including the height), the mechanical bonds between the fibers are not secured, so the structure does not get mechanical resistance. In the case of S3 and S4, the consolidation technology allows obtaining large specific masses at smaller thicknesses than the S1 and S2

\begin{tabular}{|c|c|c|c|c|c|}
\hline \multicolumn{5}{|c|}{ STATISTICAL INDICATORS ON EM SPECIFIC MASS } \\
\hline \multirow{2}{*}{ Characteristics } & \multirow{2}{*}{ Reference document } & \multicolumn{4}{|c|}{ ME Technological sample } \\
\cline { 3 - 6 } & & S1 & S2 & S3 & S4 \\
\hline Average mass/ unit area, g/m $\mathbf{m}^{\mathbf{*}}$ & \multirow{2}{*}{ SR EN 12127:2003 } & 2141.81 & 1771.40 & 2659.22 & 877.20 \\
\cline { 3 - 6 } & & 2.55 & 3.91 & 2.48 & 3.65 \\
\hline
\end{tabular}




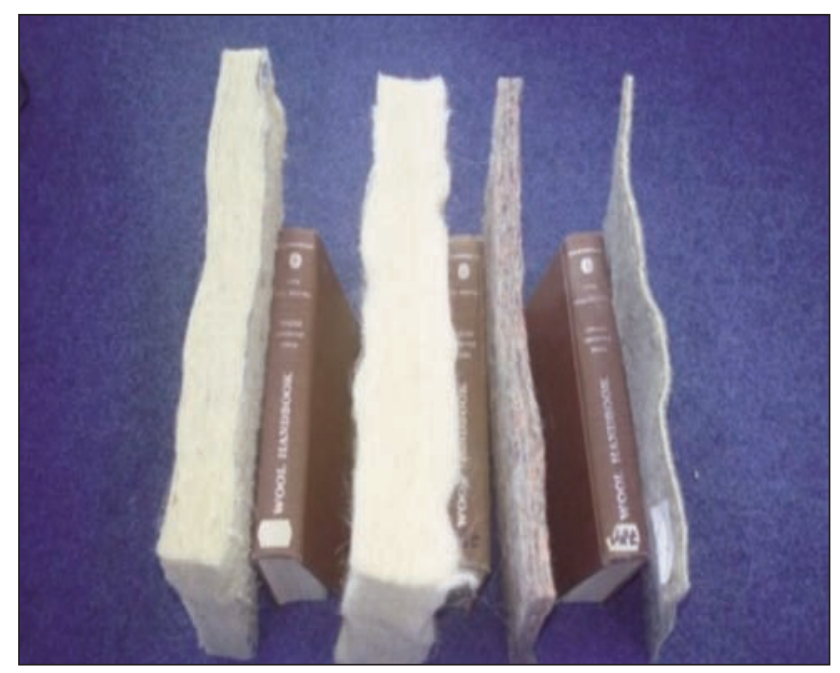

Fig. 4. Top view of the STN, with emphasis on thickness differences

structures. S3 has a specific mass greater than $203.15 \%$ over S4. The four technological variants are potentially different for recovery in the construction area, given the specific mass differences.

\section{Thickness}

The mechanical bonding by steam hardening allows high-porosity structures to be obtained (higher volumes than bonded reinforced structures by other modes) (figure 4). For structures S1 and S2 a height of the oscillating table of the hardening equipment has been calibrated at $60 \mathrm{~mm}$. The results obtained from the measurements are presented in table 8.

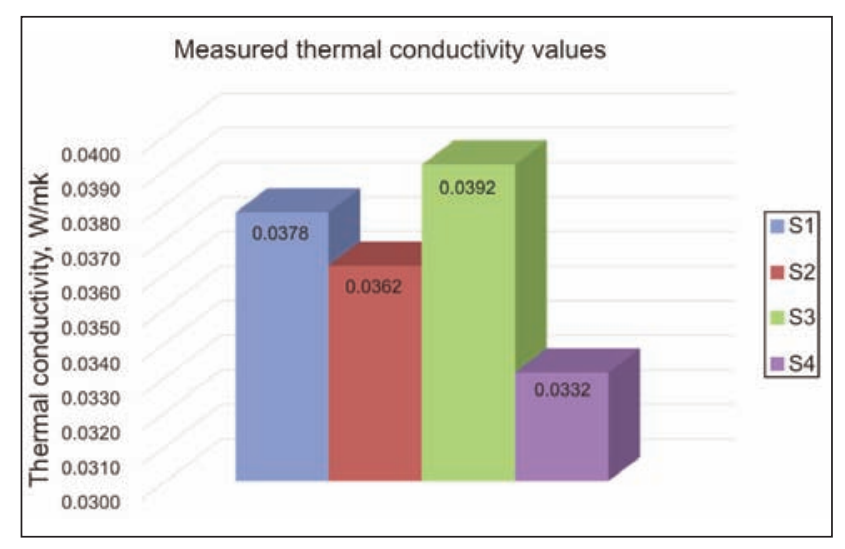

Fig. 5. Thermal conductivity of S1, S2, S3 and S4 EM [22]

Celsius [23]. The value of $\lambda$ is a material constant, and its decrease leads to an increase in the level of thermal insulation that the material can provide. Values of $\lambda$ for STN S1-4 are presented in the table 9 Figure 5 shows that the $\lambda$ value of structure $S 2$ is $4.07 \%$ smaller than $S 1$, which means that structure $\mathrm{S} 2$ is better isolator than structure $\mathrm{S} 1$ (structure $\mathrm{S} 2$ has a larger air volume than structure S2, which allows a higher convective transfer that structure S1). Structure S4 shows an $\lambda$ value of $15.34 \%$ lower than S3.

\section{Burning behaviour of NTS}

Fire behaviour test: Determination of flame propagation properties on vertically oriented specimens consists of two procedures: A. ignition of the surface, $B$. ignition of the lower end. The results of the fire

STATISTICAL INDICATORS OF EM THICKNESS

\begin{tabular}{|c|c|c|c|c|c|}
\hline \multicolumn{6}{|c|}{ STATISTICAL INDICATORS OF EM THICKNESS } \\
\hline \multirow{2}{*}{ Characteristics } & \multirow{2}{*}{ Reference document } & \multicolumn{4}{|c|}{ EM technological sample } \\
\hline & & S1 & S2 & S3 & S4 \\
\hline Average thickness, $\mathrm{mm}$ & \multirow{3}{*}{ SR EN ISO 9073-2-2000 } & 39,744 & 48,669 & 19,173 & 9,102 \\
\hline CV, \% & & 1,019 & 1,742 & 3,424 & 1,210 \\
\hline Calculated density, $\mathrm{kg} / \mathrm{m}^{3}$ & & 53.89 & 36.35 & 133.03 & 96.76 \\
\hline
\end{tabular}

Due to the different specific mass, after the bonding operation, the S1 and S2 structures did not remain at the calibrated height but decreased by $33.76 \%$ (S1) and $18.8 \%$ (S2), respectively. The thickness of S2 is $22 \%$ greater than S1. The S3 and S4 structures are more compact, with smaller thicknesses than the S1 and S2 structures, as the bonding technology allows barbed needles to train the fibers in order to fix them through the interstices of said fibrous batt (rendering compactness). Structure S4 is 55\% thicker than S3.

\section{Thermal conductivity}

The thermal conductivity $\lambda[\mathrm{W} / \mathrm{mK}]$ is equal to the amount of heat that passes for 1 hour through a $1 \mathrm{~m}$ thick material with a surface area of $1 \mathrm{~m}^{2}$ and a temperature difference on the two faces of its 1 degree

\begin{tabular}{|c|c|c|c|c|}
\hline \multicolumn{5}{|c|}{$\begin{array}{c}\text { STATISTICAL INDICATORS OF EM'S THERMAL } \\
\text { CONDUCTIVITY }\end{array}$} \\
\hline \multirow{2}{*}{ Characteristics } & \multicolumn{4}{|c|}{ EM technological sample } \\
\hline & S1 & S2 & S3 & S4 \\
\hline $\begin{array}{l}\text { Average thermal } \\
\text { conductivity, W/mK }\end{array}$ & 0.0378 & 0.0362 & 0.0392 & 0.0332 \\
\hline$C V, \%$ & 0.1186 & 0.1425 & 0.8697 & 0.1590 \\
\hline
\end{tabular}

tests of the S1, S2, S3, S4 structures (the height of the footprint) are shown in table 10.

By comparing the data obtained from table 10, it is found that: NTS S1-4 are hard to ignite, so the area subjected to flame releases unpleasant odour, 
THE TRACE HEIGHT OF THE BURNED AREA AFTER TESTING

\begin{tabular}{|c|c|c|c|c|c|c|c|c|c|}
\hline \multicolumn{2}{|c|}{$\begin{array}{c}\text { EM technological } \\
\text { sample }\end{array}$} & \multicolumn{2}{|c|}{ s1 } & \multicolumn{2}{|c|}{ S2 } & \multicolumn{2}{|c|}{ s3 } & \multicolumn{2}{|c|}{ S4 } \\
\hline Procedure & \multirow{3}{*}{$\begin{array}{c}\text { Trace } \\
\text { height, } \\
\mathrm{mm}\end{array}$} & $\mathbf{L}$ & $\mathbf{T}$ & $\mathbf{L}$ & $\mathbf{T}$ & $\mathbf{L}$ & $\mathbf{T}$ & $\mathbf{L}$ & $\mathbf{T}$ \\
\hline A & & 87 & 87 & 95 & 85 & 72 & 60 & 65 & 57 \\
\hline B & & 103 & 112 & 143 & 147 & 108 & 115 & 100 & 105 \\
\hline
\end{tabular}

$L-$ longitudinal testing; $T$ - transversal testing.

burned hooves; The trace dimensions due to the initiation flame of $40 \pm 2 \mathrm{~mm}$ (procedure A) and $25 \pm 2$ $\mathrm{mm}$ (procedure $\mathrm{B}$ ) are higher in high-volume structures (S1 and S2) than in high density structures (S3 and S4), both longitudinally and transversally, for both procedures. The smallest trace shows the S4 structure in fire testing by both procedures.

\section{Electrical resistivity}

Testing the electrical resistivity of wool fiber panels confirms their dielectric character. The average resistivity test values are shown in table 11.

From the analysis of the experimental values we find that the values are ranged between $10^{13}(\Omega)$ to $10^{14}$ $(\Omega)$, both for surface resistivity and for the resistivity of the volume, values above the resistivity values of dielectric insulating materials $\left(10^{11} \Omega\right)$, comparable to the prexiglas, teflon, air etc. [12]. It can be appreciated

Table 11

\begin{tabular}{|c|c|c|}
\hline \multicolumn{3}{|c|}{ EM ELECTRICAL RESISTIVITY } \\
\hline $\begin{array}{c}\text { EM technological } \\
\text { sample }\end{array}$ & $\begin{array}{c}\text { Surface } \\
\text { resistivity, }(\Omega)\end{array}$ & $\begin{array}{c}\text { Volume resistivity, } \\
\left(\Omega^{*} \mathbf{c m}\right)\end{array}$ \\
\hline S1 & $4,81^{*} 10^{13}$ & $5,54^{*} 10^{13}$ \\
\hline S2 & $1,08^{*} 10^{13}$ & $1,56^{*} 10^{13}$ \\
\hline S3 & $9,35^{*} 10^{13}$ & $2,51^{*} 10^{13}$ \\
\hline S4 & $1,84^{*} 10^{14}$ & $1,67^{*} 10^{14}$ \\
\hline
\end{tabular}

that the use of structures S1, S2, S3 and S4 in construction structures traversed by electric cables does not pose additional risk in case of short electric circuits.

\section{CONCLUSIONS}

The study reveals the potential for the use of wool fibers in non-conventional textile structures for thermal insulation in construction. The experimental fibrous blend consists of tanning wool, considered as tannery waste and sheared coarse wool.

For the experiments two existing technological flows, at S.C. Cora Trading \& Service SRL, for processing the fibrous blend were selected, which contain preliminary processing operations, web and batt formation and final operations. Due to the high content of impurities of mineral, animal and vegetal origin, the fleece has been subjected to 5 preliminary processing operations, where the manufacturer's own invented or with specific technological adaptations equipment was used.

For the experiments 4 technological samples of nonconventional textile structures, formed by two ways of bonding/felting (hardening - structures S1 and S2), needle punching - structures S3 and S4) have been used.

The 4 non-conventional textile structures designed and developed represent a sustainable developing potential for the manufacturer particularly and for the Romanian textile industry generally.

\section{ACKNOWLEDGEMENTS}

This work was carried out under the PNIII, Programe 2: P2 - Increasing the Romanian economic competitiveness through RDI, Subprograme 2.1. Research, development and inovation, Innovation Checks 2018, Program implemented with the support of the Executive Agency for Higher Education, Research, Development and Innovation Funding, project no. PN-III-P2-2.1-Cl-2018-0870and the publication is funded by the Minister of Research and Innovation through the Program 1 - Development of the National Research and Development System, Subprogram 1.2 - Institutional Performance - RDI excellence funding projects, Contract no. 6PFE/ 16.10.2018.

\section{BIBLIOGRAPHY}

[1] Stec, A. A., \& Hull, R. T. (2011). Assessment of the fire toxicity of building insulation materials. In: Energy and Buildings, 43(2-3), 498-506.

[2] Woolley, T. (2016). Building materials, health and indoor air quality: No breathing space? Routledge.

[3] Pavel, C. C., \& Blagoeva, D. T. (2018). Competitive landscape of the EU's insulation materials industry for energyefficient buildings - JRC Technical Reports. Joint Research Center. Luxembourg: Publication Office of the European Union.

[4] European Commission (2018). Energy.

[5] Johnson, N., Wood, E., Ingham, P., McNeil, S., \& McFarlane, I. (2003). Wool as a technical fibre. In: The Journal of The Textile Institute, 94 (Part 3: Technical Textiles).

[6] Baillie, C., \& Jayasinghe, R. (2017). Green composites: Nature and waste-based materials for a sustainable

[7] Mansour, E., Loxton, C., Elias, R. M., \& Ormondroyd, G. A. (2014). Assessment of health implications related to processing and use of natural wool insulation products. In: Environment International, 73, pp. 402-412. 
[8] Giuliano, F., Riccardo, I., Takayuki, A., Hideki, S., \& Masuhiro, T. (2003). Physical properties of wool fibers modified with isocyanate compounds. In: J. App. Sc., 89, pp. 1390-1396.

[9] Asandei, N., \& Grigoriu, A. (1983). Chimia și structura fibrelor. București, Editura Academiei Republicii Socialiste România.

[10] Stevens, J. R. \& Co. Inc. (1970). Wool Handbook - Third Enlarged Edition (Vol. 2 (2)). London: Interscience.

[11] Patnaik, A., Mvubu, M., \& Muniyasamy, S. (2015). Thermal and sound insulation materials from waste wool andrecycled polyester fibers and their biodegradation studies. In: Energy and Buildings, 92, pp. 161-169.

[12] Savio, L., \& Bosia, D. (2018). Application of Building indulation products based on natural wool and hemp fibers, advances in natural fibre composites: raw materials, processing and analysis, Springer International Publishing.

[13] Zach, J., Korjenic, A., \& Petránek, V. (2012). Performance evaluation and research of alternative thermal insulations based on sheep wool. In: Energy Build., 49, pp. 246-253.

[14] Pennacchio, R., Savio, L., \& Bosia, D. (2017). Fitness: Sheep-wool and hemp sustainable insulation panel. In: Energy Procedia, 111, pp. 287-297.

[15] Chaupin, M. T. (2013). Regional projects valuing wool in Europe. Symposium on South American Camelids and other Fibre Animals. Nantes.

[16] Kim, N. K., Lin, R. J., \& Bhattacharyya, D. (2015). Flammability characteristics of wool fibre polypropylene composites using halogen-free fire retardants. The 38th Polymer Conference \& Annual Meeting of the Polymer Society Taiwan 2015. Taipei.

[17] Caraiman, M., Netea, M., \& Taras, I. (1998). Filatura de lână - Fire - Materii prime - Amestecuri. lasi: BIT.

[18] W. Albrecht, H. F. (Éd.). (2003). Nonwoven fabrics - raw materials, manufacture, applications, characteristics, testing processes. Weinheim: WILEY-VCH Verlag GmbH \& Co. KGaA.

[19] Preda, C. (1996). Structuri și tehnologii de obținere a materialelor textile neconvenționale, laşi: BIT.

[20] Visileanu, E. (2004). Prelucrarea mecanică a fibrelor de lână și tip lână, Certex, București.

[21] Dodu, A. (Éd.). (2003). Manualul Inginerului Textilist - Tratat de inginerie textilă (Vol. 2, Partea A), AGIR, București.

[22] Optimizarea gamei de nețesute din lână pentru termo și fono izolații - RO-IZOLANA - Raport știintific și tehnic, 2018, Cod proiect: PN-III-P2-2.1-Cl-2018-0870, Cecuri de Inovare.

[23] Horga, G.; Horga, M; Hossu, I.; Avram, D. (2013). Investigation on determining the coefficient of thermal conductivity to textile materials recoverable, used for thermal protection of hot pipelines, In: Journal of Textile \& Apparel, vol. 23, Issue 2, pp. 94-100.

\author{
Authors: \\ MARIAN-CATALIN GROSU 1 \\ ALEXANDRU ALEXAN² \\ ${ }^{1}$ National R\&D Institute for Textiles and Leather, Bucharest \\ Lucrețiu Pătrășcanu street, no. 16, sector 3, postal code 030508, Bucharest, Romania \\ e-mail: certex@certex.ro \\ 2S.C. CORA TRADING \& SERVICE S.R.L., \\ Mehadiei street, no. 43, sector 6, Bucharest, Romania \\ e-mail: a.alexan@romfelt.ro \\ Corresponding author: \\ MARIAN-CATALIN GROSU \\ e-mail: catalin.grosu@certex.ro
}

